\title{
Metabolic Syndrome and Renal Injury
}

\author{
Yi-Jing Sheen ${ }^{1}$ and Wayne Huey-Herng Sheu ${ }^{2}$ \\ ${ }^{1}$ Division of Endocrinology and Metabolism, Department of Internal Medicine, Taichung Hospital Department of Health, \\ Executive Yuan, No. 199, Sec. 1, Sanmin Road, Taichung 403, Taiwan \\ ${ }^{2}$ Division of Endocrinology and Metabolism, Department of Internal Medicine, Taichung Veterans General Hospital, \\ No. 160, Sec. 3, Taichung-Kang Road, Taichung 407, Taiwan
}

Correspondence should be addressed to Wayne Huey-Herng Sheu, whhsheu@vghtc.gov.tw

Received 23 October 2010; Revised 12 December 2010; Accepted 22 December 2010

Academic Editor: Masaki Mogi

Copyright (C) 2011 Y.-J. Sheen and W. H.-H. Sheu. This is an open access article distributed under the Creative Commons Attribution License, which permits unrestricted use, distribution, and reproduction in any medium, provided the original work is properly cited.

\begin{abstract}
Both metabolic syndrome (MetS) and chronic kidney disease (CKD) are major global health issues. Current clinical markers used to reflect renal injury include albuminuria and estimated glomerular filtration rate (eGFR). Given the same eGFR level, urine albumin might be a better risk marker to predict progression of CKD and future development of cardiovascular diseases (CVDs). Serum Cystatin C is emerging as a new biomarker for early detection of renal injury associated with MetS and cardiovascular risk. In addition to each component, MetS per se influences the incidence and prognosis of renal injury and the odds ratios increased with the increase in the number of metabolic abnormalities. Hyperinsulinemia, activation of rennin-angiotensin-aldosterone system, increase of oxidative stress, and inflammatory cytokines are proposed to be the plausible biological link between MetS and CKD. Weight control, stick control of blood pressure, glucose, and lipids disorders may lead to lessening renal injury and even the subsequent CVD.
\end{abstract}

\section{Introduction}

MetS, a complicated clinicopathological entity with clustering of CVD and metabolic risk factors, includes central obesity, hypertension, dyslipidemia, and glucose intolerance. It has been pervasively recognized that individuals with MetS are associated with the increased risks of type 2 diabetes and CVD [1-3]. Abdominal fat plays an important role in MetS, because it is predictive of sensitivity to insulin $[4,5]$. It has been reported that obesity adversely affects renal function and may be associated with morbidity and mortality in patients with CKD [4]. Recent evidence also indicated that presence of MetS is associated with an increased risk of developing CKD $[6,7]$. As a matter of fact, both MetS and CKD are major global health issues with regard to the increasing prevalence of obesity and aging society [8-11]. What is more alarming is the fact that the prevalence of endstage renal disease has more than doubled in the recent ten years [9]. Although the relationship between MetS and CKD was established, the detailed understanding of quantitative association between MetS and its components implicated in kidney damage is still limited. In this paper, we will review the following issues:

(1) epidemiological association between MetS and CKD incidence and/or progression,

(2) reliable markers of MetS associated with renal injury,

(3) plausible biologic links between MetS and CKD,

(4) impact of treating the MetS on the risk of renal injury or CKD progress.

\section{Epidemiological Association between MetS and CKD Incidence and/or Progression}

The association between MetS and CKD in different populations varies with odds ratio (OR) ranging from 0.93 to 2.60 according to our review (Table 1). In a group of 118,924 nondiabetic Chinese patients with a mean followup for 3.7 years, Sun et al. reported that multivariable adjusted HR for CKD in subjects with MetS (ATP-III-MetS) was 1.30 (95\% CI, 1.24-1.36) and 1.37 (95\% CI, 1.30-1.44), evaluated 
by proteinuria and eGFR, respectively [12]. In American Indians without diabetes, it is reported that adjusted hazard ratio for incident CKD (measured by using eGFR and urinary albumin-creatinine ratio) was 1.3 (95\% CI, 1.1-1.6) [7]. In a survey conducted in nondiabetic native Americans (the intertribal heart project), the MetS was associated with a twofold increase on prevalence of microalbuminuria [13]. In The Third National Health and Nutrition Examination Survey (NHANES III), independent excess risks for CKD were hypertension, low HDL cholesterol, hypertriglyceridaemia, fasting hyperglycemia, and large waist circumference after adjustment for several confounding factors [14]. Notably, the ORs of CKD $\left(\mathrm{eGFR}<60 \mathrm{~mL} / \mathrm{min}\right.$ per $\left.1.73 \mathrm{~m}^{2}\right)$ were 2.60 (95\% CI, 1.68-4.03) and 1.89 (95\% CI, 1.34-2.67) in patients with or without MetS, respectively. This study also found that even mildly elevated blood pressure or mild hyperglycemia may portend an increased risk of CKD and microalbuminuria. Remarkablely, high blood pressure was the most powerful predictor of CKD in patients with MetS and with the OR of 2.66 (95\% CI, 1.62-4.35) [14, 15]. In Atherosclerosis Risk in Communities (ARIC) study, a 9year follow-up survey of 10,096 nondiabetic patients, the OR was 1.43 (95\% CI, 1.18-1.73) for the development of CKD in subjects with MetS [16]. Furthermore, the OR was 1.24 (95\% CI, 1.01-1.51) even after being adjusted for the subsequent development of diabetes and hypertension [16]. Accordingly, it is suggested that diabetes and hypertension were responsible for the renal injury progress. In addition, previous studies also suggested that dyslipidemia may also affect the prognosis of CKD [17-20]. Observations in the Modification Diet Renal Disease (MDRD) cohort indicated that low high-density lipoprotein (HDL) cholesterol predicts faster CKD progression [14, 21].

The findings of several previous studies conducted different ethnicities have that MetS per se affected CKD. A population-based study of native American adults resulted in multivariate-adjusted ORs of CKD for patients with 0 or 1 component of the MetS; patients with 2,3,4, and 5 components of $\mathrm{CKD}$ had multivariate-adjusted ORs of 2.21 (CI, 1.16 to 4.24 ), 3.38 (CI, 1.48 to 7.69 ), 4.23 (CI, 2.06 to 8.63 ), and 5.85 (CI, 3.11 to 11.0 ), respectively. The corresponding multivariate-adjusted ORs of microalbuminuria for patients with 3,4 , and 5 components were 1.62 (CI, 1.10 to 2.38 ), 2.45 (CI, 1.55 to 3.85 ), and 3.19 (CI, 1.96 to 5.19 ), respectively [14]. Another study in the US showed that the OR for microalbuminuria was 1.8 for one MetS component, 1.8 (95\% CI, 1.0 to 3.2) for two components, and 2.3 (95\% CI, 1.1 to 4.9 ) for three or more components (versus no traits) after controlling age, sex, smoking, body mass index, education, and family histories of diabetes and kidney disease [13]. A cross-sectional survey of Chinese adults resulted that the multivariate-adjusted ORs (95\% CI) of CKD in participants with and without the MetS were 1.64 (1.16-2.32) and 1.36 (1.07-1.73). Compared to participants without any component of the MetS, the multivariate-adjusted ORs (95\% CI) of CKD were 1.51 (1.02, $2.23), 1.50(0.97,2.32), 2.13(1.30,3.50)$, and $2.72(1.50,4.93)$ for those with $1,2,3$, and 4 or 5 components, respectively. The corresponding multivariate-adjusted ORs (95\% CI) of elevated serum creatinine were $1.11(0.88,1.40), 1.39$ (1.07, $2.04), 1.47(1.06,2.04)$, and $2.00(1.32,3.03)$, respectively [26].

In summary, high blood pressure and hyperglycemia seem to be the most powerful predictors of CKD in subjects with MetS. Several population-based studies supported the effect of MetS on CKD even after adjusting for the influences of diabetes and hypertension. Although the ORs of renal injury in different ethnicities were varied widely (Table 1), all these results suggested that OR was higher in patients with MetS than those without even adjusting for age and gender. Furthermore, previous studies also suggested that the ORs of renal injury increased with the increase in the number of metabolic abnormalities, and the findings seem to be independent of ethnicity. These findings suggest that MetS per se is an important causative factor for CKD.

\section{Reliable Markers of the Renal Injury}

3.1. The Definitions of Metabolic Syndrome. In 1988, "Syndrome X" was introduced by Reaven, who proposed that insulin resistance plays a crucial role in glucose intolerance, hyperinsulinemia, hypertension, increased plasma triglyceride (TG), and decreased HDL cholesterol, all of which are associated with atherosclerosis and increased risk of coronary artery disease $[1,33]$. The potential causes of insulin resistance include the unhealthy life style, obesity, and male, genetic, and environmental factors [34-37]. World Health Organization (WHO) designated the clustering of the cardiovascular and metabolic risk factors as "MetS" [38]. Other diagnostic criteria of MetS include National Cholesterol Education Program Adult Treatment Panel (NCEPATP III) [2, 39] and International Diabetes Federation (IDF) [40]. Each diagnostic criterion has its essential criteria, for example, central obesity is a prerequisite for the MetS according to the IDF criteria, but microalbuminuria is considered a criterion only by the WHO. Recently, a crosssectional epidemiological study of Taiwan population had reported that the adjusted ORs of microalbuminuria based on five different definitions of MetS are varied (Table 2) [41]. Insulin resistance is considered to be the key mechanism of MetS [1, 42-44], but it is difficult to be quantified. In order to increase predictive power, some experts suggest that more related biomarkers may be needed, such as high-sensitivity C-reactive protein, uric acid, and other inflammation marker [36, 45-48].

3.2. The Reliable Markers of the Renal Injury. In general, biomarkers are used for diagnosis, severity classification, and outcome prediction. We will discuss two traditional biomarkers, eGFR and urine albumin, and one new marker serum cystatin $C[6,7,9,14,23,27,50-55]$. Which of them is the most reliable and powerful marker in evaluating patients with MetS remains controversial.

3.2.1. eGFR. Among individuals with $\mathrm{CKD}$, the stages are defined based on the level of GFR, which is estimated by a formula based on the value of creatinine [56]. CKD shares 
TABLE 1: OR of CKD in MetS: population-based studies.

(a)

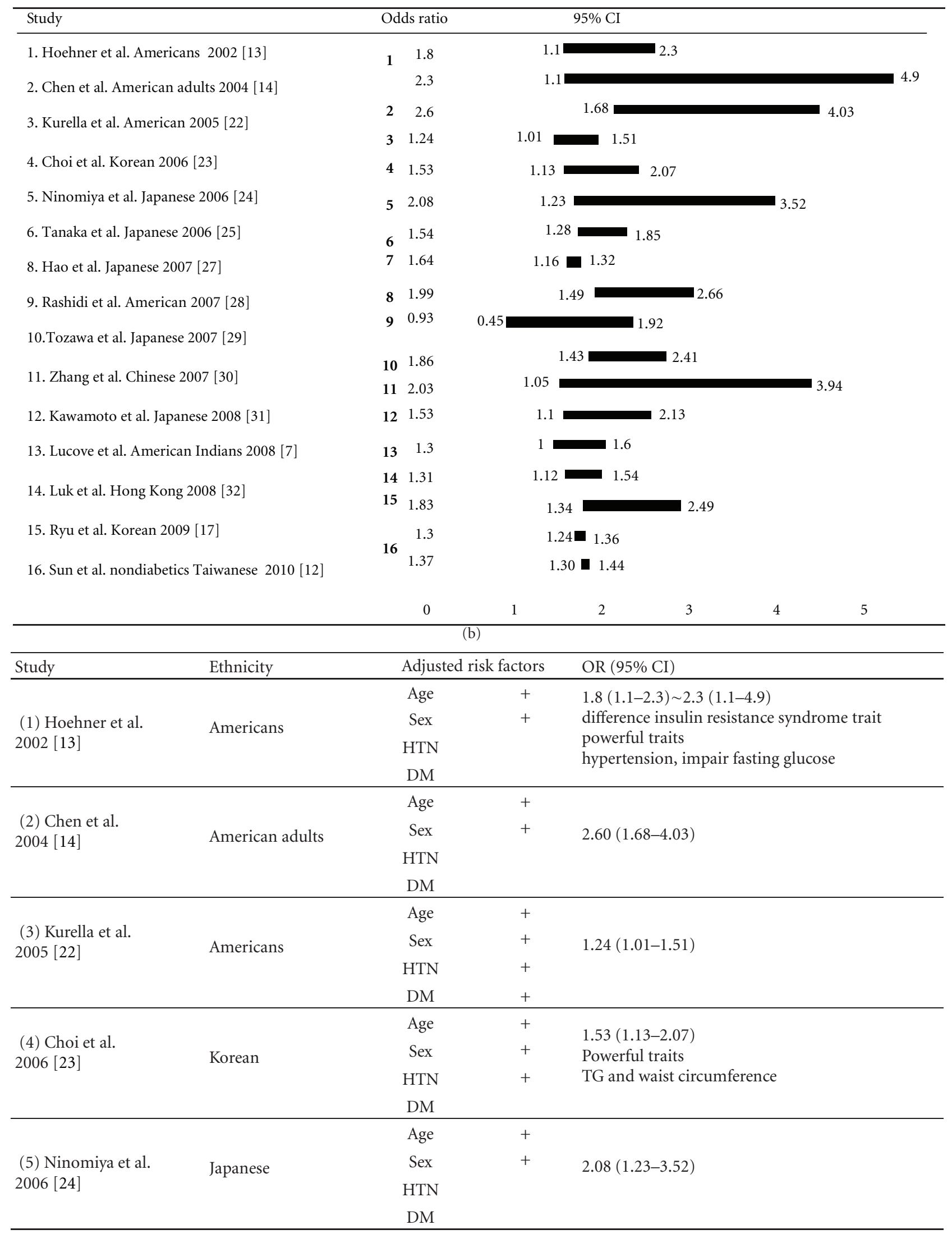


(b) Continued.

\begin{tabular}{|c|c|c|c|c|}
\hline Study & Ethnicity & \multicolumn{2}{|c|}{ Adjusted risk factors } & OR $(95 \% \mathrm{CI})$ \\
\hline \multirow{4}{*}{$\begin{array}{l}\text { (6) Tanaka et al. } \\
2006 \text { [25] }\end{array}$} & \multirow{4}{*}{ Japanese } & Age & + & \multirow{4}{*}{$1.54(1.28-1.85)$} \\
\hline & & Sex & + & \\
\hline & & HTN & & \\
\hline & & $\mathrm{DM}$ & & \\
\hline \multirow{4}{*}{$\begin{array}{l}\text { (7) Chen et al. } \\
2007[26]\end{array}$} & \multirow{4}{*}{ Chinese adults } & Age & + & \multirow{4}{*}{$1.64(1.16-1.32)$} \\
\hline & & Sex & + & \\
\hline & & HTN & & \\
\hline & & DM & & \\
\hline \multirow{4}{*}{$\begin{array}{l}\text { (8) Hao et al. } \\
2007 \text { [27] }\end{array}$} & \multirow{4}{*}{ Japanese } & Age & + & \multirow{4}{*}{$1.99(1.49-2.66)$} \\
\hline & & Sex & + & \\
\hline & & HTN & & \\
\hline & & $\mathrm{DM}$ & & \\
\hline \multirow{4}{*}{$\begin{array}{l}\text { (9) Rashidi et al. } \\
2007 \text { [28] }\end{array}$} & \multirow{4}{*}{ Americans } & Age & + & \multirow{4}{*}{$0.93(0.45-1.92)$} \\
\hline & & Sex & + & \\
\hline & & HTN & + & \\
\hline & & $\mathrm{DM}$ & & \\
\hline \multirow{4}{*}{$\begin{array}{l}\text { (10) Tozawa et al. } \\
2007 \text { [29] }\end{array}$} & \multirow{4}{*}{ Japanese } & Age & + & \multirow{4}{*}{$1.86(1.43-2.41)$} \\
\hline & & Sex & + & \\
\hline & & HTN & & \\
\hline & & $\mathrm{DM}$ & & \\
\hline \multirow{4}{*}{$\begin{array}{l}\text { (11) Zhang et al. } \\
2007 \text { [30] }\end{array}$} & \multirow{4}{*}{ Chinese } & Age & + & \multirow{4}{*}{$2.03(1.05-3.94)$} \\
\hline & & Sex & + & \\
\hline & & HTN & + & \\
\hline & & $\mathrm{DM}$ & + & \\
\hline \multirow{4}{*}{$\begin{array}{l}\text { (12) Kawamoto et al. } \\
2008 \text { [31] }\end{array}$} & \multirow{4}{*}{ Japanese } & Age & + & \multirow{4}{*}{$1.53(1.1-2.13)$} \\
\hline & & Sex & + & \\
\hline & & HTN & + & \\
\hline & & $\mathrm{DM}$ & + & \\
\hline \multirow{4}{*}{$\begin{array}{l}\text { (13) Lucove et al. } \\
2008 \text { [7] }\end{array}$} & \multirow{4}{*}{ American Indians } & Age & + & \\
\hline & & Sex & + & $1.3(1.0-1.6)$ \\
\hline & & HTN & & \\
\hline & & $\mathrm{DM}$ & & \\
\hline & & Age & + & $1.31(1.12-1.54)$ \\
\hline (14) Luk et al. & Hong Kong & Sex & + & $\begin{array}{l}\text { Powerful traits } \\
\text { central obesity, hypertriglyceridemia, }\end{array}$ \\
\hline & & HTN & & hypertension, and low BMI were independent \\
\hline & & $\mathrm{DM}$ & & predictors for CKD. \\
\hline & & Age & + & $1.83(1.34-2.49)$ \\
\hline (15) Ryu et al. & Korean & Sex & + & Powerful traits \\
\hline & & HTN & + & $\begin{array}{l}\text { increased TG and LDL cholesterol levels were } \\
\text { associated with significantly increased risk of CKD }\end{array}$ \\
\hline & & DM & + & \\
\hline & & Age & + & \\
\hline (16) Sun et al. & nondiabetc Taiwanese & Sex & + & ATP-III-MetS1.3 (1.24-1.36) \\
\hline $2010[12]$ & & HTN & + & IDF-MetS $1.37(1.30-1.44)$ \\
\hline & & $\mathrm{DM}$ & + & \\
\hline
\end{tabular}


TABle 2: Definitions of metabolic syndrome and adjusted ORs of associated microalbuminuria.

\begin{tabular}{|c|c|c|c|c|c|c|c|c|c|c|}
\hline & \multicolumn{2}{|c|}{ WHO 1998 [38] } & \multicolumn{2}{|c|}{ EGIR 1999 [49] } & \multicolumn{2}{|c|}{ NCEP ATP III 2001 [39] } & \multicolumn{2}{|c|}{ IDF 2005 [40] } & \multicolumn{2}{|c|}{ AHA 2005 [2] } \\
\hline $\begin{array}{l}\text { Essential criteria } \\
\text { Definition of MetS }\end{array}$ & \multicolumn{2}{|c|}{$\begin{array}{l}\text { IFG, IGT, or IR } \\
\text { plus } 2 \text { of other } 5 \\
\text { criteria }\end{array}$} & \multicolumn{2}{|c|}{$\begin{array}{l}\text { Insulin in top } 25 \% \\
\text { plus } 2 \text { of other } 4 \\
\text { criteria }\end{array}$} & \multicolumn{2}{|c|}{$\begin{array}{l}\text { Any } 3 \text { of } 5 \text { criteria } \\
\text { listed below }\end{array}$} & \multicolumn{2}{|c|}{$\begin{array}{l}\text { Increased waist } \\
\text { plus any of } 2 \text { of other } 4 \\
\text { criteria }\end{array}$} & \multicolumn{2}{|c|}{$\begin{array}{l}\text { Any } 3 \text { of } 5 \\
\text { criteria } \\
\text { listed below }\end{array}$} \\
\hline $\begin{array}{l}\text { Abdominal obesity } \\
\text { (men/women) }\end{array}$ & $\begin{array}{l}\text { Waist-to } \\
>0.9 / 0.85 \\
\mathrm{BMI}>30\end{array}$ & $\begin{array}{l}\text { ratio } \\
\left.\mathrm{g} / \mathrm{m}^{2}\right)\end{array}$ & Waist $\geqq$ & & Waist $>$ & $/ 80$ & $\begin{array}{l}\text { Men } \\
\geq 94 \mathrm{~cm} \\
\text { (European) } \\
\geq 90 \mathrm{~cm} \\
\text { (Chinese) } \\
\geq 90 \mathrm{~cm} \\
\text { (South } \\
\text { Asian) } \\
\geq 85 \mathrm{~cm} \\
\text { (Japanese) }\end{array}$ & $\begin{array}{l}\text { Women } \\
\geq 80 \mathrm{~cm} \\
\text { (European) } \\
\geq 80 \mathrm{~cm} \\
\text { (Chinese) } \\
\geq 80 \mathrm{~cm} \\
\text { (South } \\
\text { Asian) } \\
\geq 90 \mathrm{~cm} \\
\text { (Japanese) }\end{array}$ & Waist & $90 / 80$ \\
\hline $\begin{array}{l}\text { Triglycerides } \\
(\mathrm{nmol} / \mathrm{L})\end{array}$ & $\begin{array}{l}\geqq 1.7 \text { or } \\
\text { treatmen } \\
\text { lipid abn }\end{array}$ & rality & $\begin{array}{l}>2.0 \text { or } d \\
\text { treatmen } \\
\text { lipid abn }\end{array}$ & $\begin{array}{l}\text { this } \\
\text { ality }\end{array}$ & $\begin{array}{l}\geqq 1.7 \text { or } \\
\text { treatme } \\
\text { lipid ab }\end{array}$ & $\begin{array}{l}\text { g } \\
\text { nality }\end{array}$ & $\begin{array}{l}\geqq 1.7 \text { or drug } \\
\text { for this lipid } \\
\text { abnormality }\end{array}$ & teatment & $\begin{array}{l}\geq 1.7 \text { or } \\
\text { treatme } \\
\text { this lipi } \\
\text { abnorm }\end{array}$ & $\begin{array}{l}\text { drug } \\
\text { at for } \\
\text { ality }\end{array}$ \\
\hline $\begin{array}{l}\text { HDL cholesterol } \\
\text { (nmol/L) } \\
\text { (men/women) }\end{array}$ & $\begin{array}{l}<0.9 / 1.0 \\
\text { treatmen } \\
\text { lipid abn }\end{array}$ & $\begin{array}{l}\text { drug } \\
\text { or this } \\
\text { mality }\end{array}$ & $\begin{array}{l}<1.0 \text { or } \mathrm{d} \\
\text { treatmen } \\
\text { lipid abn }\end{array}$ & $\begin{array}{l}\text { or this } \\
\text { mality }\end{array}$ & $\begin{array}{l}<1.0 / 1 . \\
\text { treatme } \\
\text { lipid ab }\end{array}$ & $\begin{array}{l}\text { r drug } \\
\text { for this } \\
\text { rmality }\end{array}$ & $\begin{array}{l}<1.0 / 1.3 \text { or } \mathrm{d} \\
\text { treatment fo } \\
\text { abnormality }\end{array}$ & this lipid & $\begin{array}{l}<1.0 / 1 . \\
\text { drug tr } \\
\text { for } \\
\text { this lipi } \\
\text { abnorn }\end{array}$ & $\begin{array}{l}\text { or } \\
\text { atment } \\
\text { ality }\end{array}$ \\
\hline $\begin{array}{l}\text { Blood pressure } \\
(\mathrm{mmHg})\end{array}$ & $\begin{array}{l}\text { More tha } \\
\text { or drug } t \\
\text { for hyper }\end{array}$ & $\begin{array}{l}40 / 90 \\
\text { tment } \\
\text { asion }\end{array}$ & $\begin{array}{l}\text { More tha } \\
\text { or drug } \mathrm{t} \\
\text { for hyper }\end{array}$ & $\begin{array}{l}140 / 90 \\
\text { tment } \\
\text { nsion }\end{array}$ & $\begin{array}{l}\text { More th } \\
\text { or drug } \\
\text { for hyp }\end{array}$ & $\begin{array}{l}130 / 85 \\
\text { atment } \\
\text { nsion }\end{array}$ & $\begin{array}{l}\text { More than } 1 \\
\text { drug treatme } \\
\text { hypertension }\end{array}$ & $\begin{array}{l}\text { /85 or } \\
\text { it for }\end{array}$ & $\begin{array}{l}\text { More tl } \\
130 / 85 \\
\text { treatme } \\
\text { hyperte }\end{array}$ & $\begin{array}{l}\text { r drug } \\
\text { t for } \\
\text { sion }\end{array}$ \\
\hline $\begin{array}{l}\text { Fasting glucose } \\
(\mathrm{nmol} / \mathrm{L})\end{array}$ & $\begin{array}{l}\text { More tha } \\
\text { HOMA- }\end{array}$ & $\begin{array}{l}6.1 \\
>2.53 \\
\end{array}$ & More tha & & More th & 6.1 & More than 5 & & More tl & an 5.6 \\
\hline $\begin{array}{l}\text { Urinary albumin } \\
\text { excretion }\end{array}$ & $\begin{array}{l}\text { More tha } \\
\text { creatinin }\end{array}$ & $0 \mathrm{mg} / \mathrm{g}$ & - & & - & & - & & - & \\
\hline $\begin{array}{l}\text { Adjusted ORs } \\
\text { (95\% CI) of } \\
\text { microalbuminuria } \\
{[41]}\end{array}$ & $\begin{array}{l}\text { Men } \\
4.44^{* * *} \\
(2.85- \\
6.91)\end{array}$ & $\begin{array}{l}\text { Women } \\
4.16^{* * *} \\
(2.57- \\
6.73)\end{array}$ & $\begin{array}{l}\text { Men } \\
2.62^{* * *} \\
(1.49- \\
4.60)\end{array}$ & $\begin{array}{l}\text { Women } \\
1.80 \\
(0.99- \\
3.29)\end{array}$ & $\begin{array}{l}\text { Men } \\
1.99 \\
(1.31- \\
3.03)\end{array}$ & $\begin{array}{l}\text { Women } \\
2.21^{* * *} \\
(1.47- \\
3.32)\end{array}$ & $\begin{array}{l}\text { Men } \\
1.51 \\
(0.97-2.35)\end{array}$ & $\begin{array}{l}\text { Women } \\
2.29^{* * *} \\
(1.51-3.48)\end{array}$ & $\begin{array}{l}\text { Men } \\
1.64^{*} \\
(1.08- \\
2.50)\end{array}$ & $\begin{array}{l}\text { Women } \\
2.26^{* * *} \\
(1.52- \\
3.38)\end{array}$ \\
\hline
\end{tabular}

World Health Organization (WHO), European Group for the Study of Insulin Resistance (EGIR), National Cholesterol Education Program (NCEP), Adult Treatment Panel III (ATP-III), International Diabetes Federation (IDF), American Heart Association and National Heart Lung and Blood Institute (AHA/NHLBI), Metabolic Syndrome (MetS); Body mass index (BMI); high-density lipoprotein (HDL); homeostasis model assessment of insulin resistance (HOMA-IR); insulin resistance (IR). Adjusted OR (95\% CI) of microalbuminuria: a cross-sectional epidemiological study based on data from the Taichung Community Health Study $[41] .{ }^{*} P<.05 ; * *<.01 ; * * *<.001$.

many of the same risk factors as CVD, namely obesity $[9,57]$, high blood pressure [58-60], diabetes mellitus [51, 58], hypertriglyceridemia [61], low HDL level [18, 20, 51], and smoking [51]. These factors overlap with components of MetS [51]. Direct measurement of GFR value may be the most reliable measure of renal function. However, the obesity-related renal injury is also associated with glomerular hyperperfusion, hyperfiltration and causes slightly increases of GFR $[9,55]$.

3.2.2. Urine Albumin. Albuminuria is generally conceived as an attractive marker of MetS-related renal injury [6, 50]. According to the previous study, it is a better risk marker than low estimated GFR to identify individuals at risk for accelerated GFR loss [62] and even a target to improve cardiovascular and renal outcomes [63]. But some limitations should be noted in evaluation about the urinary albumin excretion for it would be affected by infection, stress condition and needed to be repeatedly measured. In addition, while end-stage renal disease causes the reduction of urine volume, albuminuria may no longer be increased with renal function progression.

3.2.3. Cystatin C. Cystatin $\mathrm{C}$ is suggested to be a new biomarker for the early detection of acute renal injury, MetS, and cardiovascular risk [52-55, 64-66]. According to the results of the Chennai Urban Rural Epidemiology Study (CURES) (MetS was defined using National Cholesterol Education Program criteria for adults modified for waist measured using the World Health Organization Asia Pacific guidelines. Serum cystin-C was estimated by a high-sensitivity particle-enhancing nephelometry assay), 
it showed that subjects with four or five metabolic abnormalities had the highest cystatin $\mathrm{C}$ level. With decreasing number of metabolic abnormalities, the cystatin $C$ levels decreased linearly $(P$ for trend $<.001$ ), and it concluded that Cystatin $\mathrm{C}$ levels are highly correlated with the number of metabolic abnormalities in Asian Indians [67]. Previous evidence suggested that the measurement of serum cystatin $\mathrm{C}$ may be useful for evaluating cardiovascular risk profile [54]. A study reported that the association of cystatin C level with all-cause and CVD mortality is even stronger than that of GFR with these outcomes in stage 3 or 4 CKD [66]. Furthermore, cystatin $\mathrm{C}$ is considered to be a marker of inflammation as well as renal function [64]. Among elderly persons without $\mathrm{CKD}$, cystatin $\mathrm{C}$ is a prognostic biomarker of risk for death, CVD and CKD, and seems to identify a preclinical state of kidney dysfunction that cannot be completely detected by measurement of serum creatinine or eGFR [65]. However, more clinical studies will be required to evaluate the clinical usefulness and cost effectiveness as compared with traditional markers.

\section{Plausible Biologic Links between MetS and CKD}

\subsection{Hyperinsulinemia, Central Obesity, Hypertension, Dyslipidemia (Figure 1)}

4.1.1. Hyperinsulinemia. Hyperinsulinemia-related insulin resistance is suspected to be the most important link between obesity and other metabolic complications leading to renal injury [9]. Insulin resistance and associated hyperinsulinemia may lead to renal involvement and injury through several different pathways. For example, activation of the reninangiotensin system (RAS) with elevated angiotensin II and aldosterone, which subsequently affect insulin/insulin-like growth factor-1 signaling pathways, reactive oxygen species formation to destroy endothelial function, would cause the development of CVD [68]. Hyperinsulinemia causes atherosclerosis through hyperglycemia and dyslipidemia and endothelial dysfunction by inducing oxidative stress and attenuating peroxisome proliferator-activated receptor (PPAR) gamma, and the downregulation of peroxisome proliferator-activated receptors (PPARs) was proved by several studies in vivo $[69,70]$. Adipokines and proinflammatory cytokines play an important role in the regulation of endovascular atherosclerosis [71].

4.1.2. Central Obesity. It is well known that patients with atherosclerotic complications are at a higher risk of CKD. Abdominal obesity is especially related to incident CKD and mortality. Inflammatory genes and genes implicated in insulin resistance are overly expressed in glomeruli of patients with obesity-related nephropathy $[34,35,72]$. Adipose tissue is the source of a novel group of hormonally active substances known as adipokines. Adipokines including IL-6, TNF- $\alpha$, and plasminogen activator inhibitor-1 (PAI1) may cause tissue damage by a direct proinflammatory mechanism or insulin resistance (some adipokines improve insulin resistance, for example, leptin, adiponectin, and Visfatin) (Table 3) $[4,73,74]$ and can be translated into inflammatory changes in the kidney $[48,71]$.

4.1.3. Hypertension. Hypertension cause, nephrosclerosis by blood pressure-dependent and -independent mechanisms. In addition, adipokines is implicated in hypertension and sodium retention secondary to obesity because it potently activates the sympathetic system, including sympathetic activity in the kidney [21]. Because of the interference with glomerular hemodynamics and with inflammatory mechanisms, the RAS is of paramount importance in CKD generation, and the angiotensin-II blockade significantly reduces cytokines and oxidative stress [75]. Reduced GFR has been found in prehypertensive patients with high blood pressure load as well as increased proteinuria, suggesting that even mild elevated blood pressure puts patients at risk of developing renal injury [19, 76-78]. Evidence of relationship between hypertension and CKD is further supported by several clinical studies. Hypertension seems to be an important risk factor of CKD (detected by eGFR and albuminuria) for the elders [78]. A recent study, using NHANES 1999-2004 data ( $n=15,332$; age $\geq 20$ years), indicated that the effects of CVD are less dramatic when hypertension and diabetes are considered [79].

4.1.4. Dyslipidemia. Dyslipidemia is related to the incidence and prognosis of CKD through the following mechanisms, such as inflammation and increased oxidative stress, which would cause endothelial damage and atherosclerosis diseases [80-82]. The mechanisms discussed above are congruent with some clinical evidences, for example, hypertriglyceridemia is an independent risk factor for CKD [61], and low HDL cholesterol predicts CKD progression [21].

4.2. Impact of Treating the MetS on the Risk of Kidney Injury or CKD Progress. The effects of MetS treatments in improving renal outcomes remain largely unexplored. We try to discuss the effects of the interventions in controlling MetS components based on limited evidence (Figure 1).

The adjusted ORs of renal injury associated with individual or multiple components of the MetS had ever been investigated. A cross-sectional survey conducted in a nationally representative sample of 15160 Chinese adults showed that the adjusted ORs of CKD with hypertension, impaired fasting glucose, waist $>102 \mathrm{~cm}$ in men or $>88 \mathrm{~cm}$ in women, high triglyceride, low HDL cholesterol were 1.17 (CI, 0.88 to 1.56 ), 1.93 (CI, 1.40 to 2.76 ), 1.95 (CI, 1.21 to 3.14), 0.92 (CI, 0.68 to 1.24 ), and 1.34 (CI, 0.98 to 1.83 ), and the ORs of renal injury increased with increasing the number of metabolic abnormalities [26].

4.2.1. Hyperglycemia. It is widely recognized that intensive treatment of hyperglycemia can significantly delay the onset of albuminuria and decrease the risk of diabetic CKD [83-85]. Some evidences about using insulin sensitizer (e.g., Thiazolidinedione and Metformin) suggested that 


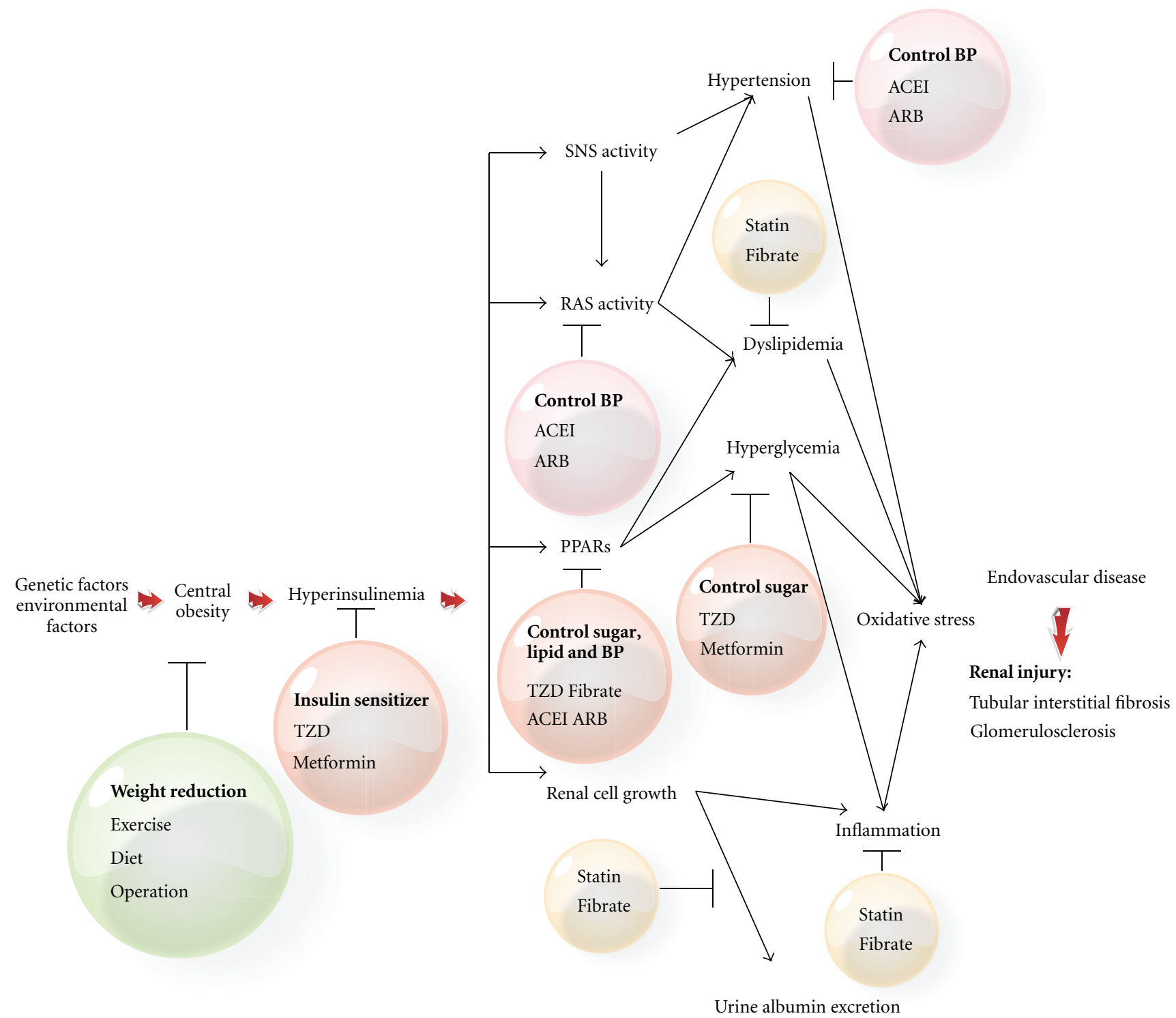

FIGURE 1: Mechanisms of insulin resistance with the consequent development of renal injury and the target of treatments. SNS: sympathetic nervous system, RAS: renin-angiotensin system, PPAR: peroxisome proliferator-activated receptors, ACEI: angiotensin-converting enzyme inhibitor, ARB: angiotensin II receptor blocker, TZD: thiazolidinediones.

improving endothelial function may be beneficial to renal injury $[86,87]$.

4.2.2. Obesity. Exercise improves insulin resistance, values of TG, HDL cholesterol, and blood pressure in patients with the MetS. A cross-sectional analysis showed that reduced renal function correlated with lower physical activity [88], and previous evidence reported the improvement of microalbuminuria after intense exercise in patients with MetS [89]. Dietary changes are as follows: a low-calorie diet can improve CKD while high protein intake may worsen proteinuria and induce renal injury [90]. Antiobesity drugs. Orlistat blocks intestinal lipase and produces modest weight loss; it did not show obvious improvment on serum creatinine in 3 months of continuous study [91]. Sibutramine is a serotonin-norepinephrine reuptake inhibitor; it may improve insulin sensitivity [92], but a previous study reported that sibutramine exhibited weight loss and reductions of cystatin C levels at 6 months, while serum creatinine levels were not reduced [93]. It has a warning on its label from the US Food and Drug Administration because of cardiovascular risk. Surgical treatment includes a variety of procedures performed on people who are obese, 
TABle 3: The Adipokines effect on insulin sensitivity.

\begin{tabular}{|c|c|c|}
\hline $\begin{array}{l}\text { Adipokines } \\
\text { (Adipose-derived } \\
\text { protein) }\end{array}$ & $\begin{array}{l}\text { Effect on insulin } \\
\text { sensitivity [73] }\end{array}$ & Clinical significance in CKD $[4,74]$ \\
\hline Resistin & Decline & $\begin{array}{l}\text { Elevated serum levels } \\
\text { Similar levels in both HD and PD } \\
\text { Associated to heart disease in dialysis [4] }\end{array}$ \\
\hline TNF- $\alpha$ & Decline & $\begin{array}{l}\text { Elevated serum level } \\
\text { Enhance gene expression of TNF- } \alpha \text { in circulating blood cells in uraemia } \\
\text { Elevated TNF- } \alpha \text { associated to increased mortality in HD } \\
\text { Anorexia and a poor nutritional status in PD [4] }\end{array}$ \\
\hline IL-6 & Decline & $\begin{array}{l}\text { Elevated serum levels } \\
\text { Reliable predictor of mortality } \\
\text { Better mortality predictor than TNF- } \alpha \text { in CKD and HD [4] }\end{array}$ \\
\hline PAI-1 & Decline & $\begin{array}{l}\text { Elevated serum level } \\
\text { Plasma PAI-1 levels increase in several chronic inflammatory states that are associated } \\
\text { with CKD } \\
\text { It may contribute to the pathogenesis of the accelerated vascular disease in this patient } \\
\text { population [74] }\end{array}$ \\
\hline Leptin & Improvement & $\begin{array}{l}\text { Markedly elevated serum level } \\
\text { Clinical marker of body fat content in dialysis } \\
\text { Associated to inflammation, atherogenic lipid profile, and insulin resistance in CKD } \\
\text { Low leptin is an independent risk factor for mortality in HD [4] }\end{array}$ \\
\hline Adiponectin & Improvement & $\begin{array}{l}\text { Elevated serum level } \\
\text { Inversely associated with metabolic risk factors in uremia } \\
\text { Inversely associated with CV events in HD } \\
\text { Improved survival and better outcome in dialysis patients [4] }\end{array}$ \\
\hline Visfatin & Improvement & $\begin{array}{l}\text { Elevated serum level } \\
\text { Anorexigenic } \\
\text { Decreased circulating levels of amino acids and triacylglycerols } \\
\text { Mortality predictor in CKD [4] }\end{array}$ \\
\hline
\end{tabular}

IL-6: interleukin-6, PAI-1: plasminogen activator inhibitor-1, TNF- $\alpha$ : tumor necrosis factor-alpha, HD: hemodialysis, PD: peritoneal dialysis.

reducing the size of the stomach with an implanted gastric banding or sleeve gastrectomy or biliopancreatic diversion with duodenal switch or gastric bypass surgery. Bariatric surgery may achieve long-term weight loss in patients with morbid obesity, improve the MetS, and reduce mortality, but the prevalence of microalbuminuria after surgery was only reduced in the diabetic group [91]. Reduction in albuminuria associated with improvement in glomerular hyperfiltration after gastroplasty has been reported [94]. However, we should notice the serious complications, such as oxalate nephropathy and nephrolithiasis, following bariatric surgery. Therefore, both surgical and nonsurgical approaches appear to be effective at reducing blood pressure and proteinuria [95]. A meta-analysis including thirteen studies reported that in smaller, short-duration studies in patients with CKD, nonsurgical weight loss interventions reduce proteinuria and blood pressure and prevent further decline in renal function; while in morbidly obese patients with glomerular hyperfiltration, surgical interventions normalize GFR and reduce blood pressure and microalbuminuria [96].

4.2.3. Hypertension. Blood pressure control helps in reducing CVD risk and CKD progression [97-101]. A continuous study of 8.8 to 12.2 years stint in evaluating the progression of CKD, which was defined as a doubling of the serum creatinine level, a diagnosis of end-stage renal disease, or death, and showed that intensive blood-pressure control (the mean blood pressure was $130 / 78 \mathrm{mmHg}$ in the intensive-control group and $141 / 86 \mathrm{mmHg}$ in the standard-control group) had no effect on kidney disease progression but may lead to differential effects on intensive blood-pressure control in patients with and those without baseline proteinuria [100]. Different antihypertensive drugs may have different effects on the protection of CKD [101]. Angiotension II signaling and subsequent oxidative stress in adipose tissue may be potential targets for the prevention of atherosclerotic cardiovascular disease in MetS and also in metabolic syndromebased CKD [75], and a previous study reported that the Angiotensin-converting enzyme inhibitors (ACEIs) appear to be more effective than beta blockers or dihydropyridine calcium channel blockers in slowing GFR decline [101]. ACEI is recommended for the treatment of hypertension in patients with CKD and is considered a prognostic factor of CKD [102]. Previous evidences suggested that angiotensinreceptor blockers (ARBs) could reduce proteinuria, but the results are variable. A study provided that $A R B$ inhibits albumin-elicited proximal tubular cell apoptosis and injury in vitro [103]. A meta-analysis from January 1990 to September 2006 also reported that the ARBs reduce proteinuria, and 
the reduction in proteinuria from $\mathrm{ARB}$ and $\mathrm{ACEI}$ is similar [104].

4.2.4. Dyslipidemia. Fibrate therapy can decrease TG, increase HDL cholesterol, improve insulin sensitivity, and reduce the mesangium-induced glumerular matrix deposition [105]. Statin therapy can decrease LDL, TG, reduce inflammation, and improve endothelial function [106-109]. The current data are based on effects of proteinuria [110].

\section{Relationship between MetS, Renal Injury, and CVD}

It is known that CKD is associated with decreased cardiac function, ventricular hypertrophy, diastolic dysfunction, and increased risk of adverse cardiovascular events [111]. The components of MetS may contribute to the pathophysiological interactions between heart and kidney in type 4 cardiorenal syndrome and cause subsequent cardiac damage (traditional risk factors are diabetes, hypertension, low HDL cholesterol, and physical inactivity; nontraditional risk factors are albuminuria, oxidative stress, or high sympathetic tone) $[111,112]$. A recent study reported the association between MetS, CKD, and left ventricular hypertrophy (LVH) and suspected that the combination of MetS and CKD is a strong risk for $\mathrm{LVH}$ as well as a strong and independent predictor of subsequent CVD [113]. Furthermore, a previous study indicated that the coexistence of early CKD with MetS could increase the accuracy of risk prediction for CVD mortality [114].

\section{Conclusions}

In addition to the effect of diabetes and hypertension, MetS is related to the incidence and prognosis of renal injury and CKD. MetS-associated renal injury may predict the subsequent CVD and even the mortality. Further studies about the MetS components that are implicated in renal damage can help to establish the targets in intervention of MetS in order to prevent CKD and CVD.

\section{References}

[1] D. Pei, S. W. Kuo, D. A. Wu et al., "The relationships between insulin resistance and components of metabolic syndrome in Taiwanese Asians," International Journal of Clinical Practice, vol. 59, no. 12, pp. 1408-1416, 2005.

[2] S. M. Grundy, J. I. Cleeman, S. R. Daniels et al., "Diagnosis and management of the metabolic syndrome: an American Heart Association/National Heart, Lung, and Blood Institute scientific statement-executive summary," Critical Pathways in Cardiology, vol. 4, no. 4, pp. 198-203, 2005.

[3] W. H. H. Sheu, S. Y. Chuang, W. J. Lee, S. T. Tsai, P. Chou, and C. H. Chen, "Predictors of incident diabetes, metabolic syndrome in middle-aged adults: a 10-year followup study from Kinmen, Taiwan," Diabetes Research and Clinical Practice, vol. 74, no. 2, pp. 162-168, 2006.
[4] P. Iglesias and J. J. Díez, "Adipose tissue in renal disease: clinical significance and prognostic implications," Nephrology Dialysis Transplantation, vol. 25, no. 7, pp. 2066-2077, 2010.

[5] G. A. Rosito, J. M. Massaro, U. Hoffmann et al., "Pericardial fat, visceral abdominal fat, cardiovascular disease risk factors, and vascular calcification in a community-based sample the framingham heart study," Circulation, vol. 117, no. 5, pp. 605-613, 2008.

[6] I. T. Lee, C. N. Huang, W. J. Lee, H. S. Lee, and W. H. H. Sheu, "Aggravation of albuminuria by metabolic syndrome in type 2 diabetic Asian subjects," Diabetes Research and Clinical Practice, vol. 81, no. 3, pp. 345-350, 2008.

[7] J. Lucove, S. Vupputuri, G. Heiss, K. North, and M. Russell, "Metabolic syndrome and the development of CKD in American Indians: the Strong Heart Study," American Journal of Kidney Diseases, vol. 51, no. 1, pp. 21-28, 2008.

[8] C. H. Chang, W. Y. Shau, Y. D. Jiang et al., “Type 2 diabetes prevalence and incidence among adults in Taiwan during 1999-2004: a national health insurance data set study," Diabetic Medicine, vol. 27, no. 6, pp. 636-643, 2010.

[9] A. Savino, P. Pelliccia, F. Chiarelli, and A. Mohn, "Obesityrelated renal injury in childhood," Hormone Research in Paediatrics, vol. 73, no. 5, pp. 303-311, 2010.

[10] S. B. Prasad et al., "Prevalence, detection, and management of the metabolic syndrome in patients with acute myocardial infarction: role of an obesity-centric definition," Cardiology Research and Practice, vol. 2010, Article ID 814561, 7 pages, 2010.

[11] Y. Wang, X. Chen, M. J. Klag, and B. Caballero, "Epidemic of childhood obesity: implications for kidney disease," Advances in Chronic Kidney Disease, vol. 13, no. 4, pp. 336-351, 2006.

[12] F. Sun, Q. Tao, and S. Zhan, "Metabolic syndrome and the development of chronic kidney disease among 118924 nondiabetic Taiwanese in a retrospective cohort: original Article," Nephrology, vol. 15, no. 1, pp. 84-92, 2010.

[13] C. M. Hoehner, K. J. Greenlund, S. Rith-Najarian, M. L. Casper, and W. M. McClellan, "Association of the insulin resistance syndrome and microalbuminuria among nondiabetic native Americans. The Inter-Tribal Heart Project," Journal of the American Society of Nephrology, vol. 13, no. 6, pp. 1626-1634, 2002.

[14] J. Chen, P. Muntner, L. L. Hamm et al., "The metabolic syndrome and chronic kidney disease in U.S. adults," Annals of Internal Medicine, vol. 140, no. 3, pp. 167-I39, 2004.

[15] C. L. Chou and TE. C. Fang, "Incidental chronic kidney disease in metabolic syndrome," Tzu Chi Medical Journal, vol. 22, no. 1, pp. 11-17, 2010.

[16] K. Kundhal and C. E. Lok, "Clinical epidemiology of cardiovascular disease in chronic kidney disease," NephronClinical Practice, vol. 101, no. 2, pp. c47-c52, 2005.

[17] S. Ryu, Y. Chang, H. Y. Woo et al., "Time-dependent association between metabolic syndrome and risk of CKD in Korean men without hypertension or diabetes," American Journal of Kidney Diseases, vol. 53, no. 1, pp. 59-69, 2009.

[18] V. Chawla, T. Greene, G. J. Beck et al., "Hyperlipidemia and long-term outcomes in nondiabetic chronic kidney disease," Clinical Journal of the American Society of Nephrology, vol. 5, no. 9, pp. 1582-1587, 2010.

[19] J. Lea, D. Cheek, D. Thornley-Brown et al., "Metabolic syndrome, proteinuria, and the risk of progressive CKD in hypertensive African Americans," American Journal of Kidney Diseases, vol. 51, no. 5, pp. 732-740, 2008. 
[20] P. Muntner, J. Coresh, J. C. Smith, J. Eckfeldt, and M. J. Klag, "Plasma lipids and risk of developing renal dysfunction: the atherosclerosis risk in communities study," Kidney International, vol. 58, no. 1, pp. 293-301, 2000.

[21] C. Zoccali, "Overweight, obesity and metabolic alterations in chronic kidney disease," Prilozi, vol. 30, no. 2, pp. 17-31, 2009.

[22] M. Kurella, J. C. Lo, and G. M. Chertow, "Metabolic syndrome and the risk for chronic kidney disease among nondiabetic adults," Journal of the American Society of Nephrology, vol. 16, no. 7, pp. 2134-2140, 2005.

[23] H. S. Choi, S. H. Ryu, and K. B. Lee, "The relationship of microalbuminuria with metabolic syndrome," NephronClinical Practice, vol. 104, no. 2, pp. c85-c93, 2006.

[24] T. Ninomiya, Y. Kiyohara, M. Kubo et al., "Metabolic syndrome and CKD in a general Japanese population: the Hisayama Study," American Journal of Kidney Diseases, vol. 48, no. 3, pp. 383-391, 2006.

[25] H. Tanaka, Y. Shiohira, Y. Uezu, A. Higa, and K. Iseki, "Metabolic syndrome and chronic kidney disease in Okinawa, Japan," Kidney International, vol. 69, no. 2, pp. 369374, 2006.

[26] J. Chen, D. Gu, C. S. Chen et al., "Association between the metabolic syndrome and chronic kidney disease in Chinese adults," Nephrology Dialysis Transplantation, vol. 22, no. 4, pp. 1100-1106, 2007.

[27] Z. Hao, T. Konta, S. Takasaki et al., "The association between microalbuminuria and metabolic syndrome in the general population in Japan: the Takahata study," Internal Medicine, vol. 46, no. 7, pp. 341-346, 2007.

[28] A. Rashidi, A. Ghanbarian, and F. Azizi, "Are patients who have metabolic syndrome without diabetes at risk for developing chronic kidney disease? Evidence based on data from a large cohort screening population," Clinical Journal of the American Society of Nephrology, vol. 2, no. 5, pp. 976-983, 2007.

[29] M. Tozawa, C. Iseki, K. Tokashiki et al., "Metabolic syndrome and risk of developing chronic kidney disease in Japanese adults," Hypertension Research, vol. 30, no. 10, pp. 937-943, 2007.

[30] L. Zhang, L. Zuo, F. Wang et al., "Metabolic syndrome and chronic kidney disease in a Chinese population aged 40 years and older," Mayo Clinic Proceedings, vol. 82, no. 7, pp. 822827, 2007.

[31] R. Kawamoto, K. Kohara, Y. Tabara, and T. Miki, "An association between metabolic syndrome and the estimated glomerular filtration rate," Internal Medicine, vol. 47, no. 15, pp. 1399-1406, 2008.

[32] A. O. Y. Luk, W. Y. So, R. C. W. Ma et al., "Metabolic syndrome predicts new onset of chronic kidney disease in 5,829 patients with type 2 diabetes A 5-year prospective analysis of the Hong Kong diabetes registry," Diabetes Care, vol. 31, no. 12, pp. 2357-2361, 2008.

[33] G. M. Reaven, "Role of insulin resistance in human disease," Diabetes, vol. 37, no. 12, pp. 1595-1607, 1988.

[34] H.-J. Tsai, C.-F. Hsiao, L.-T. Ho et al., "Genetic variants of human urea transporter-2 are associated with metabolic syndrome in Asian population," Clinica Chimica Acta, vol. 411, no. 23-24, pp. 2009-2013, 2010.

[35] YI. C. Chang, Y. F. Chiu, K. C. Shih et al., "Common PCSK1 haplotypes are associated with obesity in the Chinese population," Obesity, vol. 18, no. 7, pp. 1404-1409, 2010.

[36] W. H. H. Sheu, Y. D. I. Chen, C. Y. Yu et al., "C-reactive protein gene polymorphism 1009A $>\mathrm{G}$ is associated with serum CRP levels in Chinese men: a TCVGHAGE study," Clinica Chimica Acta, vol. 382, no. 1-2, pp. 117-123, 2007.

[37] K. D. Wu, C. F. Hsiao, L. T. Ho et al., "Clustering and heritability of insulin resistance in Chinese and Japanese hypertensive families: a Stanford-Asian Pacific Program in hypertension and insulin resistance sibling study," Hypertension Research, vol. 25, no. 4, pp. 529-536, 2002.

[38] K. G. M. M. Alberti and P. Z. Zimmet, "Definition, diagnosis and classification of diabetes mellitus and its complications. Part 1: diagnosis and classification of diabetes mellitus. Provisional report of a WHO consultation," Diabetic Medicine, vol. 15 , no. 7 , pp. 539-553, 1998.

[39] J. I. Cleeman, "Executive summary of the third report of the National Cholesterol Education Program (NCEP) expert panel on detection, evaluation, and treatment of high blood cholesterol in adults (adult treatment panel III)," Journal of the American Medical Association, vol. 285, no. 19, pp. 24862497, 2001.

[40] K. G. M. M. Alberti, P. Zimmet, and J. Shaw, "The metabolic syndrome-a new worldwide definition," Lancet, vol. 366, no. 9491, pp. 1059-1062, 2005.

[41] C. C. Lin, C. S. Liu, C. I. Li et al., "The relation of metabolic syndrome according to five definitions to cardiovascular risk factors-a population-based study," BMC Public Health, vol. 9, article 484, 2009.

[42] C. H. Hsieh, YI. J. Hung, DU. A. Wu et al., "Impact of clinical characteristics of individual metabolic syndrome on the severity of insulin resistance in Chinese adults," Journal of Korean Medical Science, vol. 22, no. 1, pp. 74-80, 2007.

[43] S. Y. Lin and W. H. H. Sheu, "An emerging link between insulin resistance and inflammation," Journal of the Chinese Medical Association, vol. 69, no. 6, pp. 245-247, 2006.

[44] M. W. Lin, C. M. Hwu, Y. H. Huang et al., "Directly measured insulin resistance and the assessment of clustered cardiovascular risks in hypertension," American Journal of Hypertension, vol. 19, no. 11, pp. 1118-1124, 2006.

[45] C. H. Chang, YI. M. Chen, YA. W. Chuang et al., "Relationship between hyperuricemia (HUC) and metabolic syndrome (MS) in institutionalized elderly men," Archives of Gerontology and Geriatrics, vol. 49, supplement 2, pp. S46S49, 2009.

[46] S. H. Sung, S. Y. Chuang, W. H. H. Sheu, W. J. Lee, P. Chou, and C. H. Chen, "Relation of adiponectin and highsensitivity C-reactive protein to pulse-wave velocity and $\mathrm{N}$-terminal pro-B-type natriuretic peptide in the general population," American Journal of Cardiology, vol. 103, no. 10, pp. 1411-1416, 2009.

[47] W. H. H. Sheu and Y. H. Tseng, "Uric acid: an additional component of metabolic syndrome?" Journal of the Chinese Medical Association, vol. 69, no. 3, pp. 99-100, 2006.

[48] Y. Y. Chou, W. H. H. Sheu, Y. J. Tang et al., "Plasminogen activator inhibitor type 1 (PAI-1) is a valuable biomarker for predicting the metabolic syndrome (MS) in institutionalized elderly residents in Taiwan," Archives of Gerontology and Geriatrics, vol. 49, supplement 2, pp. S41-S45, 2009.

[49] B. Balkau and M. A. Charles, "Comment on the provisional report from the WHO consultation. European Group for the Study of Insulin Resistance (EGIR)," Diabetic Medicine, vol. 16, no. 5, pp. 442-443, 1999.

[50] B. Chen, D. Yang, Y. U. Chen, W. Xu, BO. Ye, and Z. Ni, "The prevalence of microalbuminuria and its relationships with the components of metabolic syndrome in the general population of China," Clinica Chimica Acta, vol. 411, no. 910, pp. 705-709, 2010. 
[51] E. Ritz, "Metabolic syndrome and kidney disease," Blood Purification, vol. 26, no. 1, pp. 59-62, 2008.

[52] P. Przybylowski, J. Malyszko, and J. Malyszko, "Kidney function assessed by eGFR, cystatin C and NGAL (neutrophil gelatinase-associated lipocalin) in relation to age in heart allograft recipients," Medical Science Monitor, vol. 16, no. 9, pp. CR440-CR444, 2010.

[53] S. M. Bagshaw and R. Bellomo, "Cystatin C in acute kidney injury," Current Opinion in Critical Care, vol. 16, no. 6, pp. 533-539, 2010.

[54] L. Vigil, M. Lopez, E. Condés et al., "Cystatin C is associated with the metabolic syndrome and other cardiovascular risk factors in a hypertensive population," Journal of the American Society of Hypertension, vol. 3, no. 3, pp. 201-209, 2009.

[55] S. H. Lee, S. A. Park, S. H. Ko et al., "Insulin resistance and inflammation may have an additional role in the link between cystatin $\mathrm{C}$ and cardiovascular disease in type 2 diabetes mellitus patients," Metabolism, vol. 59, no. 2, pp. 241-246, 2010.

[56] S. Uchino, "Creatinine," Current Opinion in Critical Care, vol. 16, no. 6, pp. 562-567, 2010.

[57] G. Parlongo and C. Zoccali, "Obesity and chronic kidney diseaseL'obesità corne causa di insuff icienza renale," Recenti Progressi in Medicina, vol. 101, no. 2, pp. 57-60, 2010.

[58] J. Coresh, B. C. Astor, T. Greene, G. Eknoyan, and A. S. Levey, "Prevalence of chronic kidney disease and decreased kidney function in the adult US population: Third National Health and Nutrition Examination Survey," American Journal of Kidney Diseases, vol. 41, no. 1, pp. 1-12, 2003.

[59] P. K. Whelton, T. V. Perneger, J. He, and M. J. Klag, "The role of blood pressure as a risk factor for renal disease: a review of the epidemiologic evidence," Journal of Human Hypertension, vol. 10, no. 10, pp. 683-689, 1996.

[60] M. K. Haroun, B. G. Jaar, S. C. Hoffman, G. W. Comstock, M. J. Klag, and J. Coresh, "Risk factors for chronic kidney disease: a prospective study of 23,534 men and women in Washington County, Maryland," Journal of the American Society of Nephrology, vol. 14, no. 11, pp. 2934-2941, 2003.

[61] P. H. Lee, H. Y. Chang, C. W. Tung et al., "Hypertriglyceridemia: an independent risk factor of chronic kidney disease in Taiwanese adults," American Journal of the Medical Sciences, vol. 338, no. 3, pp. 185-189, 2009.

[62] N. Halbesma, D. S. Kuiken, A. H. Brantsma et al., "Macroalbuminuria is a better risk marker than low estimated GFR to identify individuals at risk for accelerated GFR loss in population screening," Journal of the American Society of Nephrology, vol. 17, no. 9, pp. 2582-2590, 2006.

[63] S. Basi and J. B. Lewis, "Microalbuminuria as a target to improve cardiovascular and renal outcomes," American Journal of Kidney Diseases, vol. 47, no. 6, pp. 927-946, 2006.

[64] T. Okura, M. Jotoku, J. Irita et al., "Association between cystatin $\mathrm{C}$ and inflammation in patients with essential hypertension," Clinical and Experimental Nephrology, vol. 14, no. 6, pp. 584-588, 2010.

[65] M. G. Shlipak, R. Katz, M. J. Sarnak et al., "Cystatin C and prognosis for cardiovascular and kidney outcomes in elderly persons without chronic kidney disease," Annals of Internal Medicine, vol. 145, no. 4, pp. 237-246, 2006.

[66] V. Menon, M. G. Shlipak, X. Wang et al., "Cystatin C as a risk factor for outcomes in chronic kidney disease," Annals of Internal Medicine, vol. 147, no. 1, pp. 19-27, 2007.

[67] J. Surendar, K. Indulekha, V. Aravindhan, A. Ganesan, and V. Mohan, "Association of cystatin-C with metabolic syndrome in normal glucose-tolerant subjects (CURES-97)," Diabetes
Technology and Therapeutics, vol. 12, no. 11, pp. 907-912, 2010.

[68] C. Manrique, G. Lastra, M. Gardner, and J. R. Sowers, "The renin angiotensin aldosterone system in hypertension: roles of insulin resistance and oxidative stress," Medical Clinics of North America, vol. 93, no. 3, pp. 569-582, 2009.

[69] S. Z. Duan, M. G. Usher, and R. M. Mortensen, "PPARs: the vasculature, inflammation and hypertension," Current Opinion in Nephrology and Hypertension, vol. 18, no. 2, pp. 128-133, 2009.

[70] P. K. Mishra, N. Tyagi, U. Sen, I. G. Joshua, and S. C. Tyagi, "Synergism in hyperhomocysteinemia and diabetes: role of PPAR gamma and tempol," Cardiovascular Diabetology, vol. 9, article 49, 2010.

[71] J. Wesoly, K. Sikorski, C.-K. Lee, and H. A.R. Bluyssen, “Suppressor of cytokine signaling and accelerated atherosclerosis in kidney disease," Acta Biochimica Polonica, vol. 57, no. 3, pp. 251-260, 2010.

[72] Y. Wu, Z. Liu, Z. Xiang et al., "Obesity-related glomerulopathy: insights from gene expression profiles of the glomeruli derived from renal biopsy samples," Endocrinology, vol. 147, no. 1, pp. 44-50, 2006.

[73] M. A. Lazar, "How obesity causes diabetes: not a tall tale," Science, vol. 307, no. 5708, pp. 373-375, 2005.

[74] A. A. Eddy and A. B. Fogo, "Plasminogen activator inhibitor1 in chronic kidney disease: evidence and mechanisms of action," Journal of the American Society of Nephrology, vol. 17, no. 11, pp. 2999-3012, 2006.

[75] A. Kurata, H. Nishizawa, S. Kihara et al., "Blockade of angiotensin II type-1 receptor reduces oxidative stress in adipose tissue and ameliorates adipocytokine dysregulation," Kidney International, vol. 70, no. 10, pp. 1717-1724, 2006.

[76] R. Lubrano, E. Travasso, C. Raggi, G. Guido, R. Masciangelo, and M. Elli, "Blood pressure load, proteinuria and renal function in pre-hypertensive children," Pediatric Nephrology, vol. 24, no. 4, pp. 823-831, 2009.

[77] K. Hopkins and G. L. Bakris, "Hypertension goals in advanced-stage kidney disease," Clinical Journal of the American Society of Nephrology, vol. 4, supplement 1, pp. S92-S94, 2009.

[78] S. I. Hallan and P. Stevens, "Screening for chronic kidney disease: which strategy?" Journal of Nephrology, vol. 23, no. 2, pp. 147-155, 2010.

[79] A. J. Collins, J. A. Vassalotti, C. Wang et al., "Who Should Be Targeted for CKD Screening? Impact of Diabetes, Hypertension, and Cardiovascular Disease," American Journal of Kidney Diseases, vol. 53, supplement 3, pp. S71-S77, 2009.

[80] H.-C. Ou, W.-J. Lee, S.-D. Lee et al., "Ellagic acid protects endothelial cells from oxidized low-density lipoproteininduced apoptosis by modulating the PI3K/Akt/eNOS pathway," Toxicology and Applied Pharmacology, vol. 248, no. 2, pp. 134-143, 2010.

[81] H. C. Ou, F. P. Chou, T. M. Lin, C. H. Yang, and W. H. H. Sheu, "Protective effects of eugenol against oxidized LDLinduced cytotoxicity and adhesion molecule expression in endothelial cells," Food and Chemical Toxicology, vol. 44, no. 9, pp. 1485-1495, 2006.

[82] H. C. Ou, F. P. Chou, T. M. Lin, C. H. Yang, and W. H. H. Sheu, "Protective effects of honokiol against oxidized LDLinduced cytotoxicity and adhesion molecule expression in endothelial cells," Chemico-Biological Interactions, vol. 161, no. 1, pp. 1-13, 2006.

[83] F. Ismail-Beigi, T. Craven, M. A. Banerji et al., "Effect of intensive treatment of hyperglycaemia on microvascular 
outcomes in type 2 diabetes: an analysis of the ACCORD randomised trial," The Lancet, vol. 376, no. 9739, pp. 419430, 2010.

[84] UK Prospective Diabetes Study (UKPDS) Group, "Intensive blood-glucose control with sulphonylureas or insulin compared with conventional treatment and risk of complications in patients with type 2 diabetes (UKPDS 33)," The Lancet, vol. 352, no. 9131, pp. 837-853, 1998.

[85] R. R. Holman, S. K. Paul, M. A. Bethel, D. R. Matthews, and H. A. W. Neil, "10-Year follow-up of intensive glucose control in type 2 diabetes," New England Journal of Medicine, vol. 359, no. 15 , pp. 1577-1589, 2008.

[86] P. A. Sarafidis and G. L. Bakris, "Protection of the kidney by thiazolidinediones: an assessment from bench to bedside," Kidney International, vol. 70, no. 7, pp. 1223-1233, 2006.

[87] T. Matsumoto, E. Noguchi, K. Ishida, T. Kobayashi, N. Yamada, and K. Kamata, "Metformin normalizes endothelial function by suppressing vasoconstrictor prostanoids in mesenteric arteries from OLETF rats, a model of type 2 diabetes," American Journal of Physiology, vol. 295, no. 3, pp. H1165-H1176, 2008.

[88] J. Finkelstein, A. Joshi, and M. K. Hise, "Association of physical activity and renal function in subjects with and without metabolic syndrome: a review of the Third National Health and Nutrition Examination Survey (NHANES III)," American Journal of Kidney Diseases, vol. 48, no. 3, pp. 372382, 2006.

[89] S. K. Fredrickson, T. J. Ferro, and A. C. Schutrumpf, "Disappearance of microalbuminuria in a patient with type 2 diabetes and the metabolic syndrome in the setting of an intense exercise and dietary program with sustained weight reduction," Diabetes Care, vol. 27, no. 7, pp. 1754-1755, 2004.

[90] K. A. Meckling and R. Sherfey, "A randomized trial of a hypocaloric high-protein diet, with and without exercise, on weight loss, fitness, and markers of the Metabolic Syndrome in overweight and obese women," Applied Physiology, Nutrition and Metabolism, vol. 32, no. 4, pp. 743-752, 2007.

[91] T. D. Filippatos, D. N. Kiortsis, E. N. Liberopoulos, M. Georgoula, D. P. Mikhailidis, and M. S. Elisaf, "Effect of orlistat, micronised fenofibrate and their combination on metabolic parameters in overweight and obese patients with the metabolic syndrome: the FenOrli study," Current Medical Research and Opinion, vol. 21, no. 12, article 3219, pp. 19972006, 2005.

[92] Y. I. J. Hung, Y. C. Chen, D. Pei et al., "Sibutramine improves insulin sensitivity without alteration of serum adiponectin in obese subjects with Type 2 diabetes," Diabetic Medicine, vol. 22, no. 8, pp. 1024-1030, 2005.

[93] Å. Lindholm, M. Bixo, I. Björn et al., "Effect of sibutramine on weight reduction in women with polycystic ovary syndrome: a randomized, double-blind, placebo-controlled trial," Fertility and Sterility, vol. 89, no. 5, pp. 1221-1228, 2008.

[94] A. Chagnac, T. Weinstein, M. Herman, J. Hirsh, U. Gafter, and Y. Ori, "The effects of weight loss on renal function in patients with severe obesity," Journal of the American Society of Nephrology, vol. 14, no. 6, pp. 1480-1486, 2003.

[95] H. N. Ibrahim and M. L. Weber, "Weight loss: a neglected intervention in the management of chronic kidney disease," Current Opinion in Nephrology and Hypertension, vol. 19, no. 6, pp. 534-538, 2010.

[96] S. D. Navaneethan, H. Yehnert, F. Moustarah, M. J. Schreiber, P. R. Schauer, and S. Beddhu, "Weight loss interventions in chronic kidney disease: a systematic review and meta-analysis," Clinical Journal of the American Society of Nephrology, vol. 4, no. 10, pp. 1565-1574, 2009.

[97] H. R. Black, B. Davis, J. Barzilay et al., "Metabolic and clinical outcomes in nondiabetic individuals with the metabolic syndrome assigned to chlorthalidone, amlodipine, or lisinopril as initial treatment for hypertension: a report from the antihypertensive and lipid-lowering treatment to prevent heart attack trial (ALLHAT)," Diabetes Care, vol. 31, no. 2, pp. 353-360, 2008.

[98] T. Fujita, K. Ando, H. Nishimura et al., "Antiproteinuric effect of the calcium channel blocker cilnidipine added to renin-angiotensin inhibition in hypertensive patients with chronic renal disease," Kidney International, vol. 72, no. 12, pp. 1543-1549, 2007.

[99] Y. Miwa, T. Tsuchihashi, Y. Ohta et al., "Antiproteinuric effect of cilnidipine in hypertensive japanese treated with renin-angiotensin-system inhibitors-a multicenter, open, randomized trial using 24-hour urine collection," Clinical and Experimental Hypertension, vol. 32, no. 6, pp. 400-405, 2010.

[100] L. J. Appel, J. T. Wright Jr., T. Greene et al., "Intensive bloodpressure control in hypertensive chronic kidney disease," New England Journal of Medicine, vol. 363, no. 10, pp. 918-929, 2010.

[101] J. T. Wright, G. Bakris, T. Greene et al., "Effect of blood pressure lowering and antihypertensive drug class on progression of hypertensive kidney disease: results from the AASK trial," Journal of the American Medical Association, vol. 288, no. 19, pp. 2421-2431, 2002.

[102] K. Omae, T. Ogawa, and K. Nitta, "Therapeutic advantage of angiotensin-converting enzyme inhibitors in patients with proteinuric chronic kidney disease," Heart and Vessels, vol. 25, no. 3, pp. 203-208, 2010.

[103] T. Matsui, S. I. Yamagishi, S. Ueda, K. Fukami, and S. Okuda, "Irbesartan inhibits albumin-elicited proximal tubular cell apoptosis and injury In vitro," Protein and Peptide Letters, vol. 17, no. 1, pp. 74-77, 2010.

[104] R. Kunz, C. Friedrich, M. Wolbers, and J. F. E. Mann, "Meta-analysis: effect of monotherapy and combination therapy with inhibitors of the renin-angiotensin system on proteinuria in renal disease," Annals of Internal Medicine, vol. 148, no. 1, pp. 30-48, 2008.

[105] X. Ruan, F. Zheng, and Y. Guan, "PPARs and the kidney in metabolic syndrome," American Journal of Physiology, vol. 294, no. 5, pp. F1032-F1047, 2008.

[106] T. M. Lee, S. F. Su, and C. H. Tsai, "Effect of pravastatin on proteinuria in patients with well-controlled hypertension," Hypertension, vol. 40, no. 1, pp. 67-73, 2002.

[107] W. H. Sheu, Y. T. Chen, and W. J. Lee, "Improvement in endothelial dysfunction with LDL cholesterol level < $80 \mathrm{mg} / \mathrm{dl}$ in type 2 diabetic patients," Diabetes Care, vol. 24, no. 8, pp. 1499-1501, 2001.

[108] I. T. Lee, W. J. Lee, H. C. Ou, C. N. Huang, and W. H. H. Sheu, "Metabolic syndrome abating the beneficial effect of pravastatin treatment on adhesion of endothelium by monocytes in subjects with hypercholesterolemia," Metabolism, vol. 58, no. 3, pp. 416-420, 2009.

[109] W. J. Lee, W. L. Lee, Y. J. Tang et al., "Early Improvements in insulin sensitivity and inflammatory markers are induced by pravastatin in nondiabetic subjects with hypercholesterolemia," Clinica Chimica Acta, vol. 390, no. 1-2, pp. 49-55, 2008. 
[110] D. Lewis, R. Haynes, and M. J. Landray, "Lipids in chronic kidney disease," Journal of Renal Care, vol. 36, no. 1, pp. 2733, 2010.

[111] C. Ronco, M. Haapio, A. A. House, N. Anavekar, and R. Bellomo, "Cardiorenal syndrome," Journal of the American College of Cardiology, vol. 52, no. 19, pp. 1527-1539, 2008.

[112] G. Bakris, J. Vassalotti, E. Ritz et al., "National kidney foundation consensus conference on cardiovascular and kidney diseases and diabetes risk: an integrated therapeutic approach to reduce events," Kidney International, vol. 78, no. 8, pp. 726-736, 2010.

[113] Y. Iwashima, T. Horio, K. Kamide et al., "Additive interaction of metabolic syndrome and chronic kidney disease on cardiac hypertrophy, and risk of cardiovascular disease in hypertension," American Journal of Hypertension, vol. 23, no. 3, pp. 290-298, 2010.

[114] D. Martins et al., "Renal dysfunction, metabolic syndrome and cardiovascular disease mortality," Journal of Nutrition and Metabolism, vol. 2010, Article ID 167162, 8 pages, 2010. 


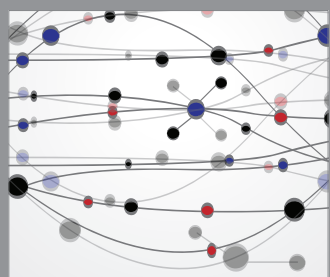

The Scientific World Journal
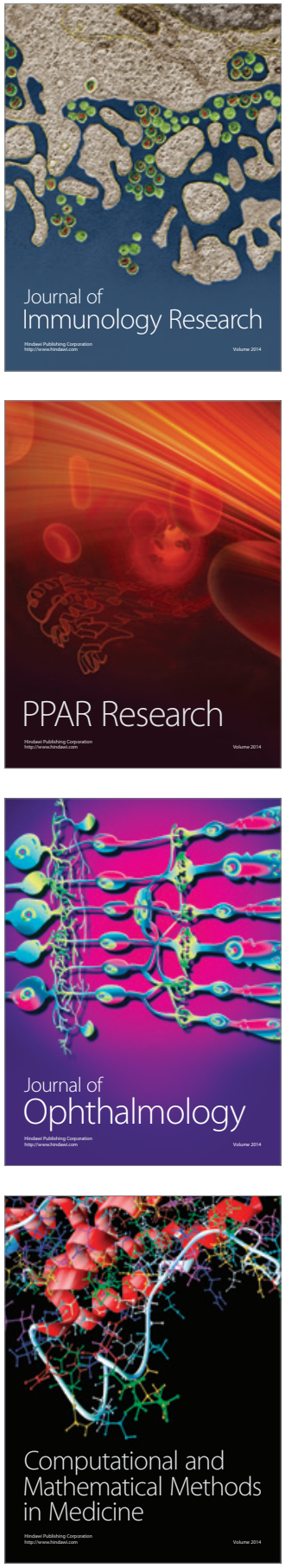

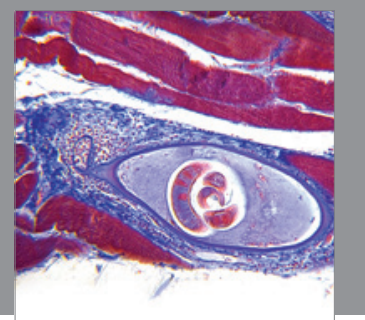

Gastroenterology

Research and Practice
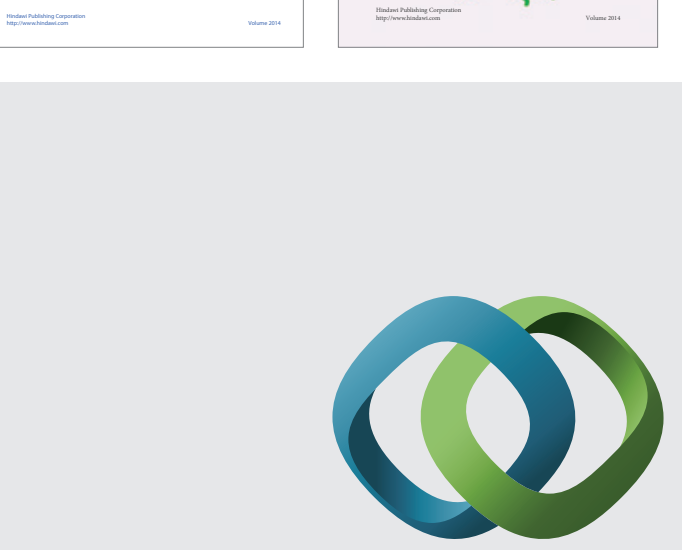

\section{Hindawi}

Submit your manuscripts at

http://www.hindawi.com
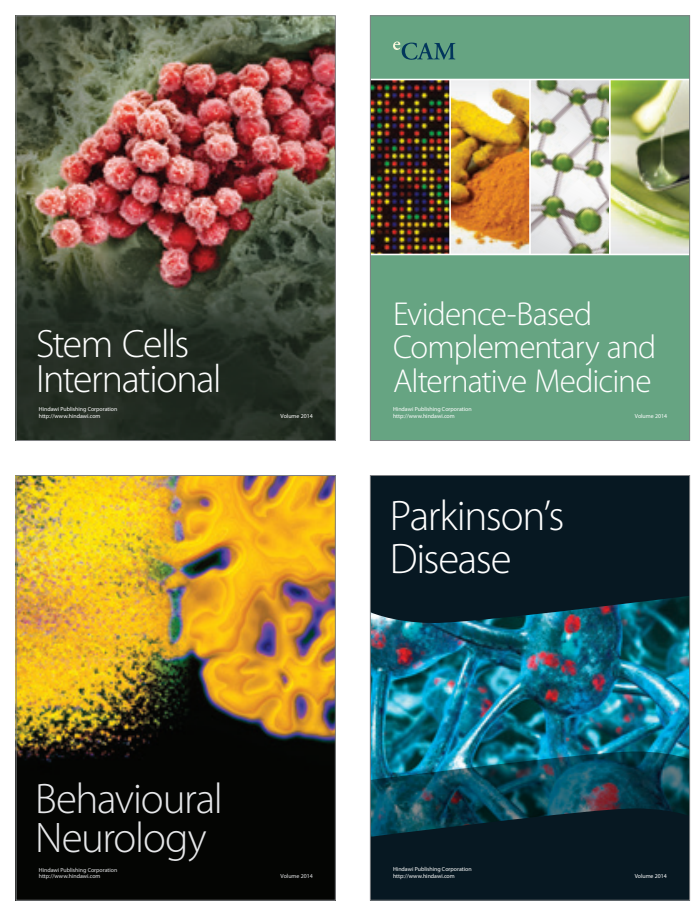

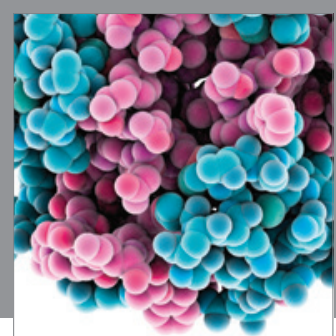

Journal of
Diabetes Research

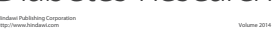

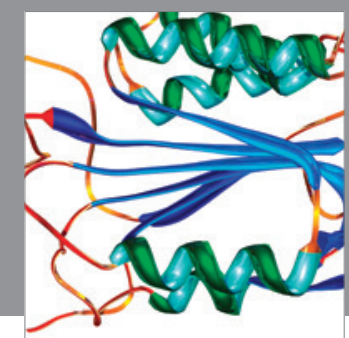

Disease Markers
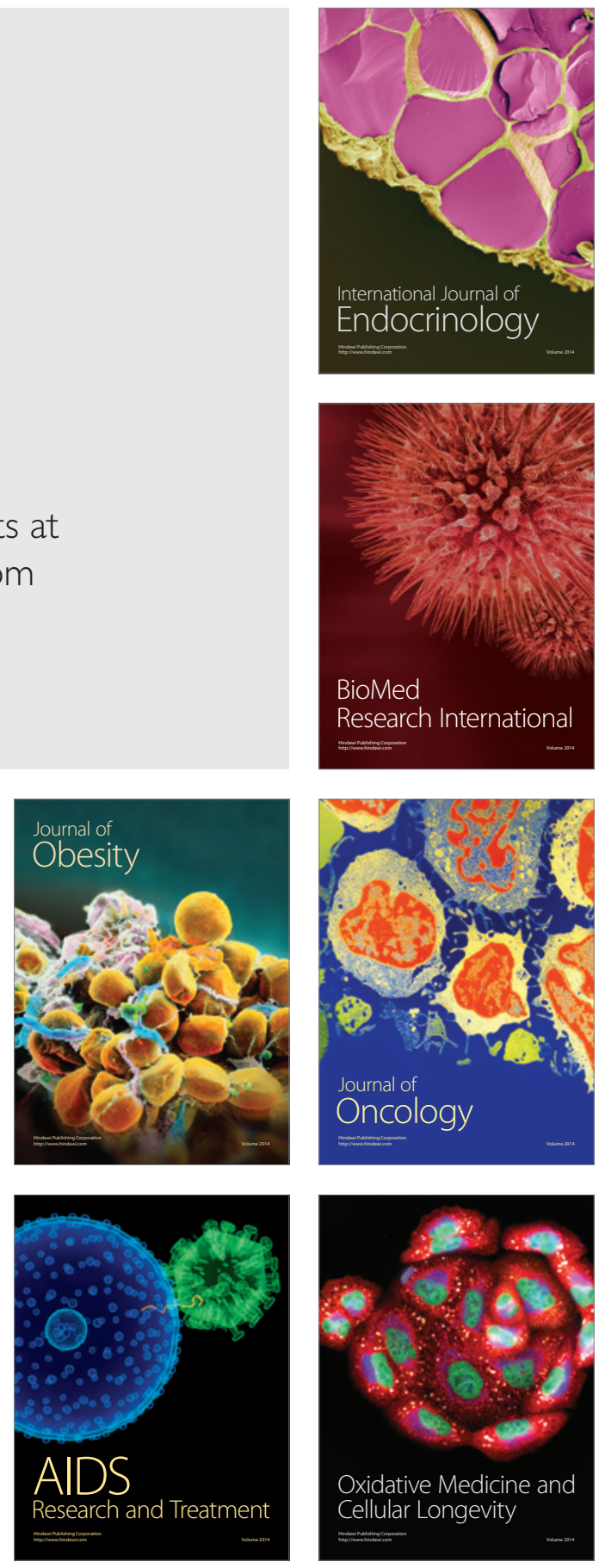